\title{
Translation into Brazilian Portuguese, cultural adaptation and evaluation of the reliability of the Disabilities of the Arm, Shoulder and Hand Questionnaire
}

A.G. Orfale,

P.M.P. Araújo,

M.B. Ferraz

and J. Natour
Disciplina de Reumatologia, Escola Paulista de Medicina, Universidade Federal de São Paulo, São Paulo, SP, Brasil

\section{Correspondence \\ J. Natour \\ Disciplina de Reumatologia \\ UNIFESP \\ Rua Botucatu, 740 \\ 04023-900 São Paulo, SP \\ Brasil \\ E-mail: jnatour@reumato.epm.br}

Publication supported by FAPESP.

Received January 14, 2004

Accepted August 12, 2004

\begin{abstract}
The objective of the present study was to translate, adapt and validate a Brazilian Portuguese version of the Disabilities of the Arm, Shoulder and Hand (DASH) Questionnaire. The study was carried out in two steps. The first was to translate the DASH into Portuguese and to perform cultural adaptation and the second involved the determination of the reliability and validity of the DASH for the Brazilian population. For this purpose, 65 rheumatoid arthritis patients of either sex (according to the classification criteria of the American College of Rheumatology), ranging in age from 18 to 60 years and presenting no other diseases involving the upper limbs, were interviewed. The patients were selected consecutively at the rheumatology outpatient clinic of UNIFESP. The following results were obtained: in the first step (translation and cultural adaptation), all patients answered the questions. In the second step, Spearman's correlation coefficients for interobserver evaluation ranged from 0.762 to 0.995 , values considered to be highly reliable. In addition, intraclass correlation coefficients ranged from 0.97 to 0.99 , also highly reliable values. Spearman's correlation coefficients and the intraclass correlation coefficients obtained during intra-observer evaluation ranged from 0.731 to 0.937 and from 0.90 to 0.96 , respectively, being highly reliable values. The Ritchie Index showed a weak correlation with Brazilian DASH scores, while the visual analog scale of pain showed a good correlation with DASH score. We conclude that the Portuguese version of the DASH is a reliable instrument.
\end{abstract}

\section{Introduction}

Several diseases interfere with the mobility of upper limb joints, including rheumatic, orthopedic and neurological disorders, amputations, and other alterations. In addition
Key words

- Disabilities of the Arm, Shoulder and Hand (DASH)

- Translation into Brazilian

Portuguese

- Disability Questionnaire

- Arthritis

- Upper limb

- Validation

- Arm to interfering with good limb functioning, these diseases cause pain, muscle weakness, instability, and compensations (1). Rheumatoid arthritis (RA) is a systemic disease, especially involving articular, periarticular and tendon structures as a result of inflammation 
of the synovial membrane. In this disease, upper limb involvement can lead to deformities disabling the articulations $(2,3)$.

The Disabilities of the Arm, Shoulder and Hand (DASH) Questionnaire (4) was developed to measure physical disability and symptoms of the upper limbs in a heterogeneous population, i.e., men and women, and individuals with mild, moderate or severe disability and a wide variety of upper extremity disorders (5). The purpose of the DASH Questionnaire is to describe differences between groups of individuals in order to compare the impact of upper limb disorders and outcome measures. This instrument was developed to evaluate disability and symptoms in single or multiple disorders of the upper limbs (5).

The DASHQuestionnaire contains 30 questions designed to measure physical function and symptoms, including two items related to physical function, six items related to symptoms, and three items that assess social functions. In addition, there are two modules of four optional items: one for athletes/musicians and another for workers (5). The importance of the DASH is that it is the only questionnaire assessing the upper limbs as a whole. The questionnaire score is calculated by applying established formulas, one of them used to analyze the first 30 questions and the other used separately for the optional modules.

The objective of the present study was to translate the DASH into Brazilian Portuguese, make a cultural adaptation and evaluate its reliability for Brazilian patients.

\section{Patients and Methods}

Translation and adaptation of the original English version of the DASH were performed according to the recommendations of Guillemin et al. $(6,7)$ and Beaton et al. (8).

\section{Translation and back translation}

Three English teachers (one of them a native English speaker) independently translated the original questionnaire, producing three different Portuguese versions of the questionnaire. The three translations were then compared and a consensus version (V1) of this translation was agreed upon.

The consensus version was then independently translated into English (back translation) by three other English teachers who were unaware of the original questionnaire. At the end of this phase, a new consensus version, called V2, was obtained and compared with the original questionnaire to determine equivalence. This new English version (V2), when compared to the original version, showed semantic and grammatical equivalence.

\section{Cultural equivalence}

A meeting was then held with health care workers (a rheumatologist, a physiotherapist and an occupational therapist) to evaluate the final DASH version. In questions 18 and 19 , which refer to recreational activities that require effort of or impact on arms, shoulders or hands and to activities during which the arm moves freely, respectively, the examples were changed because the cited sports are unknown to and thus inappropriate for Brazilian patients. In question 18, playing golf or tennis was replaced with playing volley ball or hammering. In question 19, playing Frisbee or "hitting" (baseball) was replaced with playing shuttlecock and fishing.

This Portuguese version of the DASH was applied by an interviewer to $25 \mathrm{RA}$ patients selected consecutively at the rheumatology outpatient clinic of the Federal University of São Paulo (UNIFESP). All of the patients fulfilled at least the four classification criteria for RA $(9,10)$. The mean age of this group (22 women and 3 men) was 48.25 years. All patients presented upper limb dysfunction.

All patients agreed to participate in the 
study. The main proposal of this step of the study was to determine question understanding. All questions were analyzed and those not understood were recorded. If $20 \%$ or more of the patients did not understand an item, the question was modified and tested again.

\section{Reliability and validity}

After cultural equivalence was established, the questionnaire was applied by interviewers to a new group of 40 RA patients. The DASH was applied three times, with the first two applications being performed on the same day by two investigators (investigator 1 and investigator 2 - interobserver evaluation), and the third assessment 5 to 8 days after the first application performed by investigator 1 (intra-observer evaluation). This new group of patients with RA was selected by the same procedure as used for the first group and also presented upper limb dysfunction. The mean age of these patients (36 women and 4 men) was 50.70 years.

The validity of the DASH was tested by determining its relationship with other clinical parameters commonly used for the assessment of RA patients. Clinical outcome measures included a visual analog scale (VAS) of pain in the upper limb and the Ritchie Articular Index (11), which were obtained during questionnaire application.

Inter- and intraobserver reliabilities were determined using Spearman's correlation coefficient and the intraclass correlation coefficient (ICC).

\section{Results}

Appendix 1 shows the original DASH version in English and Appendix 2 shows the final version of the DASH in Portuguese.

Table 1 lists the clinical and demographic characteristics of the 65 RA patients included in the cultural adaptation phase of the Portuguese DASH version and in the question- naire validation phase.

Spearman's correlation coefficient for interobserver assessment was 0.937 for DASH scores and 0.920 for the optional module, values considered to be statistically significant $(\mathrm{P}<0.01)$ and, therefore, highly reliable. The ICC for interobserver reliabil-

Table 1. Clinical and demographic characteristics of the 65 patients with rheumatoid arthritis, 25 included during the phase of cultural adaptation of the Portuguese version of the Disabilities of the Arm, Shoulder and Hand (DASH) Questionnaire (phase I) and 40 during the phase of intra- and interobserver reliability assessment (phase II).

\begin{tabular}{|c|c|c|}
\hline & $\begin{array}{l}\text { Phase I } \\
(N=25)\end{array}$ & $\begin{array}{l}\text { Phase II } \\
(N=40)\end{array}$ \\
\hline Mean age (years) & 48.25 & 50.7 \\
\hline Sex (female:male) & $22: 3$ & $36: 4$ \\
\hline Duration of the disease (years) & $13.63(8.02)$ & $11.39(7.80)$ \\
\hline \multicolumn{3}{|l|}{ Functional class } \\
\hline Class I & $3(12 \%)$ & $20(30.8 \%)$ \\
\hline Class II & $12(48 \%)$ & $19(29.2 \%)$ \\
\hline Class III & $10(40 \%)$ & $1(1.5 \%)$ \\
\hline DASH score sa $^{2}$ & $36.77(19.76)$ & $27.28(19.11)$ \\
\hline DASH score for the optional working module ${ }^{a}$ & $47.13(24.23)$ & $36.51(25.23)$ \\
\hline DASH scorec & - & $24.49(18.52)$ \\
\hline DASH score for the optional working modulec & - & 34.04 (23.59) \\
\hline DASH score ${ }^{b}$ & & $27.67(19.00)$ \\
\hline DASH score for the optional working module ${ }^{b}$ & - & $36.01(24.07)$ \\
\hline Time (min) of application of the DASH & 16.5 & 16.5 \\
\hline
\end{tabular}

Data are reported as means (SD). ${ }^{\text {a }}$ nitial assessment. ${ }^{b}$ Assessment performed on the same day as the initial assessment by a different examiner. ${ }^{C}$ Assessment performed after 5 to 8 days by the same initial examiner.

Table 2. Inter- and intra-observer reliability determined by Spearman's correlation coefficient and the intraclass correlation coefficient, showing the mean Disabilities of the Arm, Shoulder and Hand (DASH) scores obtained by two observers and for the assessment performed one week later in 40 patients with rheumatoid arthritis.

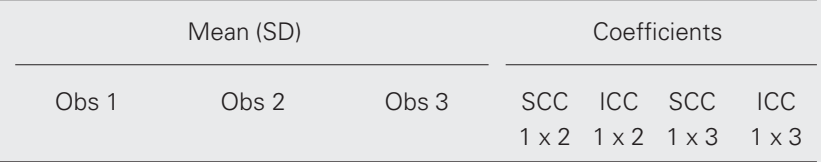

DASH $\quad 27.28(19.11) \quad 27.67(19.00) \quad 26.49(18.52) \quad 0.995 * 0.99 * 0.937 * 0.96 *$ DASH optional $36.51(25.23) \quad 36.01(24.07) \quad 34.04(23.59) \quad 0.939 * 0.97 * 0.920 * 0.95 *$ module

Data are reported as means \pm SD. Obs $1=$ initial assessment; Obs $2=$ assessment performed on the same day as the initial assessment by a different interviewer; Obs $3=$ assessment performed after 5 to 8 days by the same initial interviewer. SCC $=$ Spearman's correlation coefficient; ICC $=$ intraclass correlation coefficient. ${ }^{*} \mathrm{P}<0.01$. 
ity was 0.99 for DASH scores and 0.97 for optional module correlations $(\mathrm{P}<0.01)$.

In intra-observer assessment, Spearman's correlation coefficient was 0.99 for DASH scores and 0.95 for optional module correlations, also statistically significant $(\mathrm{P}<0.01)$ and thus reliable values. The ICC for intraobserver reliability was also significant $(\mathrm{P}<$ 0.01 ), being 0.90 for DASH scores and 0.96 for optional module correlations. Table 2 shows the mean $( \pm \mathrm{SD})$ for total DASH scores and the optional module, as well as Spearman's coefficient and the ICC.

Spearman's correlation coefficient between DASH and the optional DASH module was $0.797(\mathrm{P}<0.01)$. The correlation between DASH and VAS was $0.617(\mathrm{P}<$ $0.01)$ and the DASH correlation with Ritchie was $0.393(\mathrm{P}<0.05)$. All of the values encountered were significant but DASH correlation with the VAS was stronger than with the Ritchie Index, respectively showing values of 0.468 and $0.495(\mathrm{P}<0.01)$.

\section{Discussion}

This is the first study applying the DASH to RA patients; all previous studies of this type were performed on other diseases. Navsarikar et al. (12) studied patients with psoriatic arthritis, Rosales et al. (13) patients with carpal tunnel syndrome, and Offenbaecher et al. (14) investigated patients with shoulder pain, which can be the result of nonspecific rheumatic conditions. Dubert et al. (15) assessed patients with traumatic diseases and disorders affecting the soft tissues of the upper limb. The importance of the results obtained with the application of the DASH to RA becomes evident when considering the frequency of the disease and involvement of the upper limbs, since RA is a systemic disease that affects all joints, but particularly those of the upper limbs ranging from the shoulder joints to the minor joints of the hand. In addition, there is a paucity of quality instruments for assessing the upper limbs as a whole.

After translation, the DASH was found to be close to the Brazilian reality since only the examples in two questions needed to be modified in the Portuguese version to adapt the instrument to the Brazilian population. The first modification was related to the example in question 18 , in which playing tennis or golf was replaced with playing volley ball or hammering, since in Brazil few individuals know how to play tennis and golf is not a popularly practiced sport. Similarly, in question 19 playing Frisbee or "hitting" (baseball) was replaced with fishing or playing shuttlecock. In Brazil baseball is a rare sport and playing Frisbee is little practiced. It is important to note that these modifications did not alter the context of the question, which remained "recreational activities that require effort of or impact on the arms, shoulders or hands" and "recreational activities during which the arm is moved freely", respectively. The study by Rosales et al. (13), in which the DASH was translated into Spanish, also made changes in questions 18 and 19. In question 18 , although the examples of practicing golf and tennis were maintained, hammering and playing shuttlecock were added. However, in question 19 the example given was swimming, recalling that this question refers to free movement of the arm.

In the present study, the DASH Questionnaire was applied by interviewers since in Brazil most patients are not used to or do not have sufficient schooling to respond to self-administered questionnaires. Thus, application of the DASH by interviewers was aimed at increasing the population to which the questionnaire could be applied, sidestepping a low level of education, as has also been done with other questionnaires (1619).

Navsarikar et al. (12), studying patients with psoriatic arthritis, found a mean score of 27.5 ( $\mathrm{SD}=24.6$ ). Jain et al. (20), in a study on patients with upper limb disabilities, reported DASH scores ranging from 21 to 99 , 
with scores ranging from 21 to 40 in 4 participants, from 41 to 60 in 9 , from 61 to 80 in 8 , and from 81 to 99 in 22 individuals, with the last result being highest in comparison to other studies. By way of contrast, Beaton et al. (21), in a study involving diseases affecting the wrist, hands and shoulders, observed DASH scores similar to those reported in the studies cited earlier, with a mean score of 43.9. It is important to note that the higher the score, the poorer the condition of the patient.

In the present study, the mean duration of the disease was 13.63 years (range, 1 to 31 years). Although studying a different disease, Navsarikar et al. (12) reported a similar duration (13.11 years) for patients with psoriatic arthritis.

In the assessment of intra- and interobserver reliability, Spearman's correlation coefficient and the ICC showed highly satisfactory correlations for the DASH scores and the optional DASH module. Analysis revealed a significant correlation between the DASH and the VAS of pain in the upper limbs. However, the Ritchie Index correlation was significant but weak, probably because not only upper but also lower limb joints were inflamed in these patients, whereas the questionnaire only refers to the upper limbs. Similarly, Navsarikar et al. (12) also reported a high correlation between the DASH and inflamed joints of the upper limbs, while comparison with the total number of inflamed joints showed no correlation.

Mean DASH scores obtained during intra-observer evaluation were 27.28 ( $\mathrm{SD}=$ 19.11) and $26.49(\mathrm{SD}=18.52)$ for the first and second assessment, respectively, with a Spearman's coefficient of 0.937. Performing two assessments, Rosales et al. (13) obtained Person's correlation coefficients ranging from 0.85 to 0.97 . In contrast, during interobserver reliability evaluation, mean scores of $27.28(\mathrm{SD}=19.11)$ and $27.67(\mathrm{SD}$ $=19.00$ ) were obtained for the first and second assessment, respectively, with a mean Spearman's coefficient of 0.995 .

Rosales et al. (13) reported a high level of equivalence for the Spanish version of the DASH. Dubert et al. (15) stated that the DASH is an objective measure which provides specific scores that help in the comparison of different treatment specialties. Navsarikar et al. (12) concluded that the DASH can be used in clinical studies since it reflects disease activity and articular debilitation; however, it does not reflect deformities or disabilities adapted to during the disease process. We also found that the DASH is unable to detect deformities when the patient is already adapted to his/her new condition. However, the important fact is not how the activity was performed but that it was performed since the DASH score indicates difficulty or disability in task performance, in agreement with other investigators. Probably due to this "failure", true instead of apparent difficulties are detected. If deformities do not interfere with the execution of activities, they will not affect the DASH score.

The practical sports/music module of the DASH might generate bias since some patients do not show difficulty playing a musical instrument but have difficulty practicing sports, especially when the sport involves effort or impact. This module should be applied in studies in which the whole sample population performs the same activity; otherwise it should be optional, i.e., the module should only be applied to patients who perform the same type of sport or play the same instrument. However, further studies on this module are required.

The Brazilian Portuguese version of the DASH was found to be a reliable and valid instrument for upper limb assessment in Brazilian patients and its scores correlated strongly with the VAS of pain and weakly with the Ritchie Index. 


\section{References}

1. Amadio PC (2001). Outcome assessment in hand surgery and hand therapy: an update. Journal of Hand Surgery, 14: 63-67.

2. Felson DT (1993). Epidemiology of the rheumatic diseases. In: McCarty DJ \& Koopman WJ (Editors), Arthritis and Allied Conditions. 12th edn. Lea, Washington, DC, USA, 17-47.

3. Hough Jr AJ (1993). Pathology of rheumatoid arthritis and allied disorders. In: McCarty DJ \& Koopman WJ (Editors), Arthritis and Allied Conditions. 12th edn. Lea, Washington, DC, USA, 737-761.

4. Hudak PL, Amadio PC \& Bombardier C (1996). Development of an upper extremity outcome measure: the DASH. American Journal of Industrial Medicine, 29: 602-606.

5. McDowell IW \& Newell C (1990). Measuring Health: A Guide to Rating Scales and Questionnaires. Oxford University Press, Library of Congress Cataloguing in Publication Data, New York, Oxford, 1342.

6. Guillemin F, Bombardier C \& Beaton DE (1993). Cross-cultural adaptation of health-related quality of life measures: literature review and proposed guidelines. Journal of Clinical Epidemiology, 46: 14171432

7. Guillemin F (1995). Measuring health status across cultures. Rheumatology in Europe, 24 (Suppl 2): 102-103.

8. Beaton DE, Bombardier C, Guillemin F \& Ferraz MB (2000). Guidelines for the process of cross-cultural adaptation of self-report measures. Spine, 25: 3186-3191.

9. Arnett FC, Edworth SM, Bloch DA et al. (1988). The American Rheumatism Association 1987 revised criteria of rheumatoid arthritis. Arthritis and Rheumatism, 31: 315-324.

10. Hocheberg M, Chang RW \& Dwosh I (1992). The American College of Rheumatology 1991 revised criteria for the classification of global functional status in rheumatoid arthritis. Arthritis and Rheumatism, 35: 498-502

11. Ritchie DM, Boyle JA, Mvinnes JM, Jasani MK, Dalakos TG, Grieveson P \& Buchanan WW (1968). Clinical studies with an articular index for the assessment of joint tenderness in patients with rheumatoid arthritis. Quarterly Journal of Medicine, 147: 393-406.

12. Navsarikar A, Gladman DD, Husted JA \& Cook RJ (1999). Validity assessment of the Disabilities of the Arm, Shoulder and Hand Questionnaire (DASH) for patients with psoriatic arthritis. Journal of
Rheumatology, 26: 2191-2194.

13. Rosales RS, Delgado EB \& Lastra-Bosch ID (2002). Evaluation of the Spanish version of the DASH and Carpal Tunnel Syndrome HealthRelated Quality-of-life Instruments: cross-cultural adaptation process and reability. Journal of Hand Surgery, 27: 334-343.

14. Offenbaecher M, Ewert T, Sangha O \& Stucki G (2002). Validation of a German Version of the Disabilities of the Arm, Shoulder and Hand Questionnaire (DASH-G) (Editorial). Journal of Rheumatology, 29: 401-402.

15. Dubert T, Voche P, Dumontier C \& Dinh A (2001). Le questionnaire DASH: Adaptation française d'un outil d'évaluation internationale. Chirurgie de la Main, 20: 294-302.

16. Nusbaum L, Natour J, Ferraz MB \& Goldenberg J (2001). Translation, adaptation and validation of the Roland-Morris questionnaire Brazil Roland Morris. Brazilian Journal of Medical and Biological Research, 34: 203-210.

17. Simões MFJ (2002). Brasil Patient Knowledge Questionnaire (PKQ) e avaliação do conhecimento específico sobre a doença em pacientes com artrite reumatóide. Master's thesis, Universidade Federal de São Paulo, Escola Paulista de Medicina, São Paulo, SP, Brazil.

18. Ciconelli RM (1997). Tradução para o português e validação do questionário genérico de avaliação de qualidade de vida. Medical Outcomes 36-Item Short-form Health Survey (SF-36) (Brasil-SF-36). Doctoral thesis, Universidade Federal de São Paulo, Escola Paulista de Medicina, São Paulo, SP, Brazil.

19. Ferraz MB, Oliveira LM, Araújo PMP, Atra E \& Tugwell P (1990). Cross-cultural reliability of the physical ability dimension of the Health Assessment Questionnaire. Journal of Rheumatology, 17: 813-817.

20. Jain R, Hudak PL \& Bowen CVA (2001). Validity of health status measure in patients with ulnar wrist disorders. Journal of Hand Surgery, 14: 147-153.

21. Beaton DE, Katz JN, Fossel AH, Wright JG \& Tarasuk V (2001). Validity, reability and responsiveness of the disabilities of the arm, shoulder and hand outcome measure in different regions of the upper extremity. Journal of Hand Surgery, 14: 128-146. 
Appendix 1. Original DASH.

\section{Instructions}

This questionnaire is about your symptoms as well as your ability to perform some activities.

Please answer all the questions based on your condition last week by circling the appropriate number.

If you didn't have the opportunity to perform some of the activities last week, please try to estimate which answer would be the most correct. It doesn't matter which arm or hand you use to perform the activity; please answer based on your ability despite the way you perform the task.

Rate your ability of doing the following activities last week by circling the corresponding number:

\begin{tabular}{|c|c|c|c|c|c|}
\hline & $\begin{array}{c}\text { Not } \\
\text { difficult }\end{array}$ & $\begin{array}{l}\text { A little } \\
\text { difficult }\end{array}$ & $\begin{array}{l}\text { Average } \\
\text { difficulty }\end{array}$ & $\begin{array}{l}\text { Very } \\
\text { difficult }\end{array}$ & Unable \\
\hline 1. Open a tight jar & 1 & 2 & 3 & 4 & 5 \\
\hline 2. Write & 1 & 2 & 3 & 4 & 5 \\
\hline 3. Turn a key & 1 & 2 & 3 & 4 & 5 \\
\hline 4. Cook a meal & 1 & 2 & 3 & 4 & 5 \\
\hline 5. Push open a heavy door & 1 & 2 & 3 & 4 & 5 \\
\hline 6. Place an object on a shelf above your head & 1 & 2 & 3 & 4 & 5 \\
\hline 7. Do heavy housework (wash walls, wash floor) & 1 & 2 & 3 & 4 & 5 \\
\hline 8. Gardening & 1 & 2 & 3 & 4 & 5 \\
\hline 9. Make the bed & 1 & 2 & 3 & 4 & 5 \\
\hline 10. Carry a heavy bag or a suitcase & 1 & 2 & 3 & 4 & 5 \\
\hline 11. Carry a heavy object (more than $5 \mathrm{~kg}$ ) & 1 & 2 & 3 & 4 & 5 \\
\hline 12. Change a light bulb above your head & 1 & 2 & 3 & 4 & 5 \\
\hline 13. Wash or dry your hair & 1 & 2 & 3 & 4 & 5 \\
\hline 14. Wash your back & 1 & 2 & 3 & 4 & 5 \\
\hline 15. Put on a sweater & 1 & 2 & 3 & 4 & 5 \\
\hline 16. Use a knife to cut food & 1 & 2 & 3 & 4 & 5 \\
\hline 17. Recreational activities (play cards, knit) & 1 & 2 & 3 & 4 & 5 \\
\hline $\begin{array}{l}\text { 18. Recreational activities, which cause impact in your } \\
\text { arms, shoulders and hands (play volleyball, hammering) }\end{array}$ & 1 & 2 & 3 & 4 & 5 \\
\hline $\begin{array}{l}\text { 19. Recreational activities in which you move your arm } \\
\text { freely (fishing, badminton) }\end{array}$ & 1 & 2 & 3 & 4 & 5 \\
\hline 20. Handle transportation needs & 1 & 2 & 3 & 4 & 5 \\
\hline \multirow[t]{2}{*}{ 21. Sexual activities } & 1 & 2 & 3 & 4 & 5 \\
\hline & Nothing & A little & Average & A lot & Extremely \\
\hline \multirow{2}{*}{$\begin{array}{l}\text { 22. Last week, how much has your problem affected your } \\
\text { regular activities with family, friends, neighbors or groups? }\end{array}$} & 1 & 2 & 3 & 4 & 5 \\
\hline & No & A little & Average & A lot & Unable \\
\hline $\begin{array}{l}\text { 23. During last week, was your work or regular activities } \\
\text { limited because of your problem? }\end{array}$ & 1 & 2 & 3 & 4 & 5 \\
\hline Rate the severity of the following symptoms last week: & None & A little & Average & A lot & Extreme \\
\hline 24. Pain in the arm, shoulder or hand & 1 & 2 & 3 & 4 & 5 \\
\hline $\begin{array}{l}\text { 25. Pain in the arm, shoulder or hand while doing } \\
\text { specific activities }\end{array}$ & 1 & 2 & 3 & 4 & 5 \\
\hline 26. Pins and needles in your arm, shoulder or hand & 1 & 2 & 3 & 4 & 5 \\
\hline 27. Weakness in the arm, shoulder or hand & 1 & 2 & 3 & 4 & 5 \\
\hline \multirow[t]{2}{*}{ 28. Difficulty in moving the arm, shoulder or hand } & 1 & 2 & 3 & 4 & 5 \\
\hline & $\begin{array}{l}\text { Not } \\
\text { difficult }\end{array}$ & $\begin{array}{l}\text { Not very } \\
\text { difficult }\end{array}$ & $\begin{array}{l}\text { Average } \\
\text { difficulty }\end{array}$ & $\begin{array}{l}\text { Very } \\
\text { difficult }\end{array}$ & $\begin{array}{l}\text { So difficult that } \\
\text { I couldn't sleep }\end{array}$ \\
\hline $\begin{array}{l}\text { 29. During last week, how difficult was it for you to sleep } \\
\text { because of the pain in your arm, shoulder or hand? }\end{array}$ & 1 & 2 & 3 & 4 & 5 \\
\hline
\end{tabular}




\begin{tabular}{|c|c|c|c|c|c|}
\hline & Totally disagree & Disagree & Neither agree or disagree & Agree & Totally agree \\
\hline $\begin{array}{l}\text { 30. I feel less capable, confident and useful because of } \\
\text { my problem }\end{array}$ & 1 & 2 & 3 & 4 & 5 \\
\hline
\end{tabular}

The following questions are about the impact of your arm, shoulder or hand problem while playing a sport, musical instrument or both. If you play more than one sport, musical instrument or both, please answer about the most important for you.

Please indicate the sport or musical instrument, which is the most important for you:

$\square$ I don't play sports or musical instruments (you can skip this part).

Please circle the number that best describes your physical ability last week. Did you have any difficulty to:

1. Use the usual technique to play the musical instrument or sport?

2. Play the musical instrument or sport because of the pain in your arm, shoulder or hand?

3. Play the musical instrument or sport as well as you would like to?

4. Spend the same amount of time playing the musical instrument or sport?

\begin{tabular}{ccccc}
$\begin{array}{c}\text { Not } \\
\text { difficult }\end{array}$ & $\begin{array}{c}\text { A little } \\
\text { difficult }\end{array}$ & $\begin{array}{c}\text { Average } \\
\text { difficulty }\end{array}$ & $\begin{array}{c}\text { Very } \\
\text { difficult }\end{array}$ & $\begin{array}{c}\text { Not } \\
\text { capable }\end{array}$ \\
\hline 1 & 2 & 3 & 4 & 5 \\
1 & 2 & 3 & 4 & 5 \\
1 & 2 & 3 & 4 & 5 \\
1 & 2 & 3 & 4 & 5
\end{tabular}

The following questions are about the impact of your arm, shoulder or hand problem in your ability to work (including housework if that's your main work). Please indicate what your work is:

$\square$ I don't work (you can skip this part).

Please circle the number that best describes your physical ability last week. Did you have any difficulty to:

1. Use your usual technique to work?

2. Perform your work because of the pain in your arm, shoulder or hand?

3. Perform your work as well as you would like to?

4. Spend the same amount of time performing your work?

Calculation scores

Disability/symptom score: (Raw score - 30)/1.2

Optional module: (Raw score - 4)/0.16

\begin{tabular}{ccccc}
$\begin{array}{c}\text { Not } \\
\text { difficult }\end{array}$ & $\begin{array}{c}\text { A little } \\
\text { difficult }\end{array}$ & $\begin{array}{c}\text { Average } \\
\text { difficulty }\end{array}$ & $\begin{array}{c}\text { Very } \\
\text { difficult }\end{array}$ & $\begin{array}{c}\text { Not } \\
\text { capable }\end{array}$ \\
\hline 1 & 2 & 3 & 4 & 5 \\
1 & 2 & 3 & 4 & 5 \\
1 & 2 & 3 & 4 & 5 \\
1 & 2 & 3 & 4 & 5 \\
\hline
\end{tabular}




\section{Appendix 2. Brazilian DASH.}

\section{Instruções}

Esse questionário é sobre seus sintomas, assim como suas habilidades para fazer certas atividades.

Por favor, responda a todas as questões baseando-se na sua condição na semana passada.

Se você não teve a oportunidade de fazer uma das atividades na semana passada, por favor, tente estimar qual resposta seria a mais correta. Não importa qual mão ou braço você usa para fazer a atividade; por favor, responda baseando-se na sua habilidade independentemente da forma como você faz a tarefa.

Meça a sua habilidade em fazer as seguintes atividades na semana passada circulando a resposta apropriada abaixo:

\begin{tabular}{|c|c|c|c|c|c|}
\hline & $\begin{array}{l}\text { Não houve } \\
\text { dificuldade }\end{array}$ & $\begin{array}{l}\text { Houve pouca } \\
\text { dificuldade }\end{array}$ & $\begin{array}{l}\text { Houve dificuldade } \\
\text { média }\end{array}$ & $\begin{array}{l}\text { Houve muita } \\
\text { dificuldade }\end{array}$ & $\begin{array}{l}\text { Não conseguiu } \\
\text { fazer }\end{array}$ \\
\hline 1. Abrir um vidro novo ou com a tampa muito apertada & 1 & 2 & 3 & 4 & 5 \\
\hline 2. Escrever & 1 & 2 & 3 & 4 & 5 \\
\hline 3. Virar uma chave & 1 & 2 & 3 & 4 & 5 \\
\hline 4. Preparar uma refeição & 1 & 2 & 3 & 4 & 5 \\
\hline 5. Abrir uma porta pesada & 1 & 2 & 3 & 4 & 5 \\
\hline 6. Colocar algo em uma prateleira acima de sua cabeça & 1 & 2 & 3 & 4 & 5 \\
\hline $\begin{array}{l}\text { 7. Fazer tarefas domésticas pesadas (por exemplo: lavar paredes, } \\
\text { lavar o chão) }\end{array}$ & S, & 2 & 3 & 4 & 5 \\
\hline 8. Fazer trabalho de jardinagem & 1 & 2 & 3 & 4 & 5 \\
\hline 9. Arrumar a cama & 1 & 2 & 3 & 4 & 5 \\
\hline 10. Carregar uma sacola ou uma maleta & 1 & 2 & 3 & 4 & 5 \\
\hline 11. Carregar um objeto pesado (mais de 5 kg) & 1 & 2 & 3 & 4 & 5 \\
\hline 12. Trocar uma lâmpada acima da cabeça & 1 & 2 & 3 & 4 & 5 \\
\hline 13. Lavar ou secar o cabelo & 1 & 2 & 3 & 4 & 5 \\
\hline 14. Lavar suas costas & 1 & 2 & 3 & 4 & 5 \\
\hline 15. Vestir uma blusa fechada & 1 & 2 & 3 & 4 & 5 \\
\hline 16. Usar uma faca para cortar alimentos & 1 & 2 & 3 & 4 & 5 \\
\hline $\begin{array}{l}\text { 17. Atividades recreativas que exigem pouco esforço } \\
\text { (por exemplo: jogar cartas, tricotar) }\end{array}$ & 1 & 2 & 3 & 4 & 5 \\
\hline $\begin{array}{l}\text { 18. Atividades recreativas que exigem força ou impacto } \\
\text { nos braços, ombros ou mãos (por exemplo: jogar vôlei, martela }\end{array}$ & 1 & 2 & 3 & 4 & 5 \\
\hline $\begin{array}{l}\text { 19. Atividades recreativas nas quais você move seu braço } \\
\text { livremente (como pescar, jogar peteca) }\end{array}$ & 1 & 2 & 3 & 4 & 5 \\
\hline 20. Transportar-se de um lugar a outro (ir de um lugar a outro) & 1 & 2 & 3 & 4 & 5 \\
\hline \multirow[t]{2}{*}{ 21. Atividades sexuais } & 1 & 2 & 3 & 4 & 5 \\
\hline & $\begin{array}{l}\text { Não } \\
\text { afetou }\end{array}$ & $\begin{array}{l}\text { Afetou } \\
\text { pouco }\end{array}$ & $\begin{array}{l}\text { Afetou } \\
\text { medianamente }\end{array}$ & $\begin{array}{l}\text { Afetou } \\
\text { muito }\end{array}$ & $\begin{array}{l}\text { Afetou } \\
\text { extremamente }\end{array}$ \\
\hline \multirow[t]{2}{*}{$\begin{array}{l}\text { 22. Na semana passada, em que ponto o seu problema } \\
\text { com braço, ombro ou mão afetou suas atividades normais } \\
\text { com família, amigos, vizinhos ou colegas? }\end{array}$} & 1 & 2 & 3 & 4 & 5 \\
\hline & $\begin{array}{l}\text { Não } \\
\text { limitou }\end{array}$ & $\begin{array}{l}\text { Limitou } \\
\text { pouco }\end{array}$ & $\begin{array}{l}\text { Limitou } \\
\text { medianamente }\end{array}$ & $\begin{array}{l}\text { Limitou } \\
\text { muito }\end{array}$ & $\begin{array}{l}\text { Não conseguiu } \\
\text { fazer }\end{array}$ \\
\hline $\begin{array}{l}\text { 23. Durante a semana passada, o seu trabalho ou atividades } \\
\text { diárias normais foram limitadas devido ao seu problema } \\
\text { com braço, ombro ou mão? }\end{array}$ & 1 & 2 & 3 & 4 & 5 \\
\hline Meça a gravidade dos seguintes sintomas na semana passada: & Nenhuma & Pouca & Mediana & Muita & Extrema \\
\hline 24. Dor no braço, ombro ou mão & 1 & 2 & 3 & 4 & 5 \\
\hline $\begin{array}{l}\text { 25. Dor no braço, ombro ou mão quando você fazia } \\
\text { atividades específicas }\end{array}$ & 1 & 2 & 3 & 4 & 5 \\
\hline 26. Desconforto na pele (alfinetadas) no braço, ombro ou mão & 1 & 2 & 3 & 4 & 5 \\
\hline
\end{tabular}



28. Dificuldade em mover braço, ombro ou mão
27. Fraqueza no braço, ombro ou mão

\begin{tabular}{ccccc}
1 & 2 & 3 & 4 & 5 \\
1 & 2 & 3 & 4 & 5 \\
\hline dificuldade & Pouca & Média & Muita & Tão difícil \\
dificuldade & difuldade & $\begin{array}{c}\text { que você não } \\
\text { pôde dormir }\end{array}$ \\
\hline
\end{tabular}

29. Durante a semana passada, qual a dificuldade que você teve para dormir por causa da dor no seu braço, ombro ou mão?

$$
1
$$

2
3
5

\begin{tabular}{|c|c|c|c|c|c|}
\hline & $\begin{array}{l}\text { Discordo } \\
\text { totalmente }\end{array}$ & Discordo & $\begin{array}{l}\text { Não concordo } \\
\text { nem discordo }\end{array}$ & Concordo & $\begin{array}{l}\text { Concordo } \\
\text { totalmente }\end{array}$ \\
\hline $\begin{array}{l}\text { 30. Eu me sinto menos capaz, menos confiante e menos útil } \\
\text { por causa do meu problema com braço, ombro ou mão }\end{array}$ & 1 & 2 & 3 & 4 & 5 \\
\hline
\end{tabular}

As questões que se seguem são a respeito do impacto causado no braço, ombro ou mão quando você toca um instrumento musical, pratica esporte ou ambos.

Se você toca mais de um instrumento, pratica mais de um esporte ou ambos, por favor, responda com relação ao que é mais importante para você. Por favor, indique o esporte ou instrumento que é mais importante para você:

$\square$ Eu não toco instrumentos ou pratico esportes (você pode pular essa parte)

\begin{tabular}{|c|c|c|c|c|c|}
\hline $\begin{array}{l}\text { Por favor circule o número que melhor descreve sua habilidade } \\
\text { física na semana passada. Você teve alguma dificuldade para: }\end{array}$ & Fácil & $\begin{array}{l}\text { Pouco } \\
\text { difícil }\end{array}$ & $\begin{array}{l}\text { Dificuldade } \\
\text { média }\end{array}$ & $\begin{array}{l}\text { Muito } \\
\text { difícil }\end{array}$ & $\begin{array}{l}\text { Não } \\
\text { conseguiu fazer }\end{array}$ \\
\hline $\begin{array}{l}\text { 1. Uso de sua técnica habitual para tocar instrumento } \\
\text { ou praticar esporte? }\end{array}$ & 1 & 2 & 3 & 4 & 5 \\
\hline $\begin{array}{l}\text { 2. Tocar o instrumento ou praticar o esporte por causa de dor no } \\
\text { braço, ombro ou mão? }\end{array}$ & 1 & 2 & 3 & 4 & 5 \\
\hline $\begin{array}{l}\text { 3. Tocar seu instrumento ou praticar o esporte tão bem quanto } \\
\text { você gostaria? }\end{array}$ & 1 & 2 & 3 & 4 & 5 \\
\hline $\begin{array}{l}\text { 4. Usar a mesma quantidade de tempo tocando seu instrumento } \\
\text { ou praticando o esporte? }\end{array}$ & 1 & 2 & 3 & 4 & 5 \\
\hline
\end{tabular}

As questões seguintes são sobre o impacto do seu problema no braço, ombro ou mão em sua habilidade em trabalhar (incluindo tarefas domésticas se este é seu principal trabalho).

Por favor, indique qual é o seu trabalho:

$\square$ Eu não trabalho (você pode pular essa parte)

Por favor, circule o número que melhor descreve sua habilidade física na semana passada. Você teve alguma dificuldade para:

1. Uso de sua técnica habitual para seu trabalho?

2. Fazer seu trabalho usual por causa de dor em seu braço, ombro ou mão?

3. Fazer seu trabalho tão bem quanto você gostaria?

4. Usar a mesma quantidade de tempo fazendo seu trabalho?

\begin{tabular}{ccccc} 
Fácil & $\begin{array}{r}\text { Pouco } \\
\text { difícil }\end{array}$ & $\begin{array}{c}\text { Dificuldade } \\
\text { média }\end{array}$ & $\begin{array}{r}\text { Muito } \\
\text { difícil }\end{array}$ & $\begin{array}{r}\text { Não } \\
\text { conseguiu fazer }\end{array}$ \\
\hline 1 & 2 & 3 & 4 & 5 \\
1 & 2 & 3 & 4 & 5 \\
1 & 2 & 3 & 4 & 5 \\
1 & 2 & 3 & 4 & 5
\end{tabular}

Cálculo do escore do DASH

Para se calcular o escore das 30 primeiras questões, deverá ser utilizada a seguinte fórmula:

(Soma dos valores das 30 primeiras questões - 30)/1,2

Para o cálculo dos escores dos módulos opcionais, estes deverão ser calculados separadamente, utilizando a seguinte fórmula:

(Soma dos valores - 4)/0,16 